\title{
Delimitation of the Coastal Transition Zone in the Gulf of Guayaquil, Ecuador
}

\author{
W. Pozo ${ }^{1}$, M. M. Jordán ${ }^{2} \&$ T. Sanfeliu ${ }^{3}$ \\ ${ }^{1}$ Instituto de Investigaciones de Recursos Naturales, Universidad de Guayaquil, Avenida 25 de Julio y Pío \\ Jaramillo, Guayaquil, Ecuador \\ ${ }^{2}$ Departamento de Agroquímica y Medio Ambiente, Universidad Miguel Hernández, Avda. de la Universidad \\ $\mathrm{s} / \mathrm{n}, 03202$ Elche (Alicante), Spain \\ ${ }^{3}$ Departamento de Ciencias Agrarias y del Medio Natural, Universitat Jaume I, Campus de Riu Sec, 12080 \\ Castellón, Spain
}

Correspondence: M. M. Jordán, Departamento de Agroquímica y Medio Ambiente, Universidad Miguel Hernández, Avda. de la Universidad s/n, 03202 Elche (Alicante), Spain. E-mail: manuel.jordan@umh.es

Received: July 5, 2012 Accepted: July 20, 2012 Online Published: August 10, 2012

doi:10.5539/jgg.v4n3p81 URL: http://dx.doi.org/10.5539/jgg.v4n3p81

\begin{abstract}
The article presents a methodology for the delimitation of the coastal transition zone (CTZ) and the identification of zones with distinct soil properties in the Gulf of Guayaquil (GG), Ecuador. The Gulf was chosen as study area for its urban, economic and ecological potential, more in particular for its rich marine and agricultural resources, and biodiversity. Soil physical and chemical methods, such as soil salinity indices, physical and chemical parameters, coupled with multivariate analysis enabled the delimitation of the CTZ and the grouping of the studied soil transets in three clusters with distinct properties, located in the GG from the limit of the mangrove swamp. Whereas the average conductance in the swamp area is around $27.17 \mathrm{mS} \mathrm{cm}{ }^{-1}$, inland to the isoline called the coastal transit zone soil salinity on average is $4 \mathrm{mS} \mathrm{cm}^{-1}$. The coastal transition zone has an average width of $4.2 \mathrm{~km}$, which can be characterized by three clusters. Clusters 1 and 2 show similarities in their physical and chemical soil parameters, clearly different from the soil properties of cluster 3 . The characteristics of each cluster is related to its location within the study area.
\end{abstract}

Keywords: Gulf of Guayaquil, mangrove swamp, coastal transition zone, salinity index, physcial and chemical soil parameters, cluster analysis

\section{Introduction}

According to CPPS (2006) soils are a natural system developed from a mixture of minerals and organic remains under the influence of the climate and the geo-biological environment. Saline-sodic soils are those where salt accumulation occurs within them (Jordan et al., 2004). Coastal saline soils are produced by the intrusion of saltwater in which the chemical composition of the salt corresponds to that of intruding saltwater. Continental saline soils are produced by a rise in surface water rich in salt, or by deficient washing of the root zone, where salts from irrigating water have accumulated (Navarro-Pedreño, 2007). Saline soils, according to Brady (1974), are those that contain a concentration of neutral soluble salts, enough to interfere with the natural vegetation. The conductivity of the substract in these soils is general larger than $4 \mathrm{mS} \mathrm{cm}^{-1}$. In the United States of America a value of $4 \mathrm{mS} \mathrm{cm}^{-1}$ is considered critical for agriculture (Lennon, 1977).

The classification of saline and sodic soils is based on the content of soluble salts from the substratum and by the percentage of the cation exchange capacity occupied by sodium. The classification bases are the following: Richards (1954), cited by Lennon (1977), mentions that three soils can be ranked in the following three classes: a) saline soils; b) saline-sodic soils; and c) non-saline sodic soils. The main charactestics of each class are:

a) Saline soils are soils with the electrical conductivity of the saturation extract greater than $15 \%$ of the cation exchange capacity, and whose $\mathrm{pH}$ is generally lower than 8.5 due to an excess.

b) Saline-sodic soils are those where the electrical conductivity of the saturation extract is greater than $4 \mathrm{mS}$ $\mathrm{cm}^{-1}$ at $25^{\circ} \mathrm{C}$, the exchangeable sodium is greater than $15 \%$ of the cation exchange capacity, and whose $\mathrm{pH}$ is generally less than 8.5 due to anexcess of soluble salts. 
c) Non-saline sodic soils with an electrical conductivity of the saturation extract less than $4 \mathrm{mS} \mathrm{cm}^{-1}$ at $25^{\circ} \mathrm{C}$, and the exchangeable sodium constitutes more than $15 \%$ of the total exchangeable capacity. These soils are called black alkali and their $\mathrm{pH}$ values oscillate between 8.5 and 10 . When calcium carbonate is low to non present in these soils, the $\mathrm{pH}$ drops to 6 , affecting negatively the phsical condition and the permeability.

According to Yánez (1986) and Smith (1963) the mixing of saltwater and freshwater near the coast line results in a salinity gradient from the coast to land inwards. Two typical ecosystems have been developed: coastal lagoon and estuary, with different geologic and geomorphological origin. However, the geographical proximity of both ecosystems and the comparable environmental conditions explains the ecological similarities between both ecosystems, and therefore are often referred to as lagoon estuarine system.

A coastal transition zone CTZ is a strip of continental soil that influences both the agricultural area as well as the estuarine zone (Yánez, 1989; Barton \& Arístegui, 2004). Establishment of the Gulf of Guayaquil's coastal transition zone would be beneficial for guiding the policies and decision-making processes oriented to the better utilization and management of the natural resources for respectively aquaculture and agricultural development, taking at the same time care for the conservation of the ecology of the estuarine lagoon environment. Great biological productivity in the gulf waters with the presence of mangrove swamps on the estuary surely limits the organic matter contribution from the incoming rivers (Martino \& Able, 2003). The influence of various marine currents, the convergence of different water masses, the predominant estuarine conditions, and the mixing of marine and fluvial environments have been researched (CAAM, 1996). The aim of this study, i.e. studying the characteristics of the interaction zone between delta areas and the adjacent land surface, is completely in line with LOICZ (2010) (land-ocean interaction in the coastal zone), a core project of the International Geosphere-Biosphere Programme (IGBP) and the International Human Dimensions Programme on Global Environmental Change (IHDP). LOICZ aims to provide science that contributes towards understanding the Earth system in order to inform, educate and contribute to the sustainability of the world's coastal zone. Therefore LOICZ seeks to inform the scientific community, policymakers, managers and stakeholders on the relevance of global environmental change in the coastal zone. Also the project described herein tried investigating the continuous changes in the biology, chemistry and physics of the Gulf of Guayaquil.

The main objective was to delimit the CTZ in the GG based on salinity indices and the characterization of the soils physicochemical properties to establish similarities and differences among groups by multivariate analysis (Brink \& Cowles, 1991). The specific objectives were: i) to determine the salinity of 15 soil transects around the GG; ii) to delimit the $\mathrm{CTZ}$ in the GG based on salinity indices; iii) to identify the appropriate and restrictive areas for bio-aquatic cultivation (shrimp farming); iv) to establish the restriction zone for agricultural cultivation; and v) to characterize the soil physical-chemical variability of the CTZ in the Gulf multivariate analysis. The study is based on the analysis of 12 soil physical and chemical parameters in 15 transects with a total length of 5 $\mathrm{km}$ from the swamp area land inwards, with 6 equally spaced sampling points in each transect.

\section{Materials}

\subsection{Study Area}

The Gulf of Guayaquil (GG), indicated in the work of Montaño and Sanfeliu (2008), is the biggest Gulf on the Pacific Coast of South America and receives the drainage of the Guayas River Estuary (Figure 1). The GG possesses unique characteristics consisting of an important diversity in marine species. Agriculture and shrimp farms have always been the livelihood of the area. The cold, nutrient-rich water brought to the surface by upwelling drives the system's extraordinary productivity. This ecosystem is the result of the Humboldt current and the multitude of rivers, charged with sediments and nutrients, draining from the Andean mountain range. The GG is considered the most important production area of artisanal and industrial fisheries in Ecuador (Montaño, 2010).

The main watercourse feeding the GG is the Guayas River formed by the juncture of the Daule and Babahoyo rivers and their affluents, draining the water from the Guayas River basin, one of the most important river basins in Ecuador. The Guayas River has the largest watershed in South America west of the Andes Mountains. It has an area 32,130 $\mathrm{km}^{2}$, in nine provinces: Los Ríos, Guayas, Bolívar, Manabí, Cañar, Pichincha, Azuay, Chimborazo and Cotopaxi. The river discharges into the Gulf of Guayaquil 36,572 cubic hectometers of water every year. The basin hosts $40 \%$ of the country's total population, including the population of the city of Guayaquil. As stated by CAAM (1996) the Guayas River basin has the greatest potential for agriculture and fishery of the South American countries located at the west-side of the Andean mountain range, bordering the Pacific Ocean. 
The topography of the coastal transition zone is relatively flat, composed of alluvial soil formations. The climate is wet tropic to dry tropic in the western sector adjacent to the Santa Elena Peninsula, home of the tropical thorn woodland.

In 1985, the Ecuatorian government declared mangrove conservation to be in the public interest, and by 1986 there were 362,742 hectares of mangrove swamps and saline prairies declared protected forests. However, recently a significant expansion of schrimp farming pools went hand in hand with a destruction of the mangrove swamp area. Based on to the National Aquaculture Association (2000) in Ecuador there were more than 170,000 hectares of shrimp pool fisheries, where only 50,454 hectares were operating legally. Data from the Mangrove Network (Redmanglar Internacional, 2002) were 89,386 hectares of shrimp fisheries in existence in 1984. In 1999 this area had increased to 207,000 hectares. Considering that the original mangrove swamp areas exceeded 300,000 hectares, this conversion signifies a loss of at least $50 \%$ of the cover from these swamps in recent years. Further $70 \%$ of the mangrove swamps has been eliminated since shrimp farming activities began in 1967 (Bravo, 2003). In some cases, shrimp fisheries have actually been installed within agricultural soils, with the consequent risk of salinization. In 2007, the National Association of Aquaculture carried out a study to determine the number of hectares under shrimp cultivation and the production. This study was conducted with the Coastal Resources Management Project, the Direction of the Merchant Marine, and the Ecuadorian Exportation Plan. Financing came from the European Union (Personal Communication Cesar Monge, 2008). The resolution VII.21 of the RAMSAR Convention celebrated in Costa Rica in 1999, referring to conservation improvements and the adequate use of interior sea wetlands, calls for suspending the promotion, creation of new installations, and expansion of unsustainable and harmful aquaculture activities on coastal wetlands.

\subsection{Sampling Strategy}

The research area from the current study was located in the coastal zone of the northern vertex of the Guayas River estuary. Fifteen transects were established at approximately perpendicular angles to the coastline. Each transect comprised six sampling stations placed at one-kilometer intervals, covering a distance of five kilometers each. The transects begin at the edge of the mangrove swamp and move inland, resulting in a total of 90 stations. The transect positions were pre-established, as they constitut a representative zone due to inherent hydric conditions and tidal influence. The locations of these transects are shown in Figure 1. At each of the 90 stations soil samples were collected at depths between $0-20 \mathrm{~cm}$, with approximate weights of $2 \mathrm{~kg}$, and placed into sealed plastic bags until their arrival at the laboratory. They were dried in the open air, grained, seived through a $6 \mathrm{~mm}$ sieve, and stored for further processing.

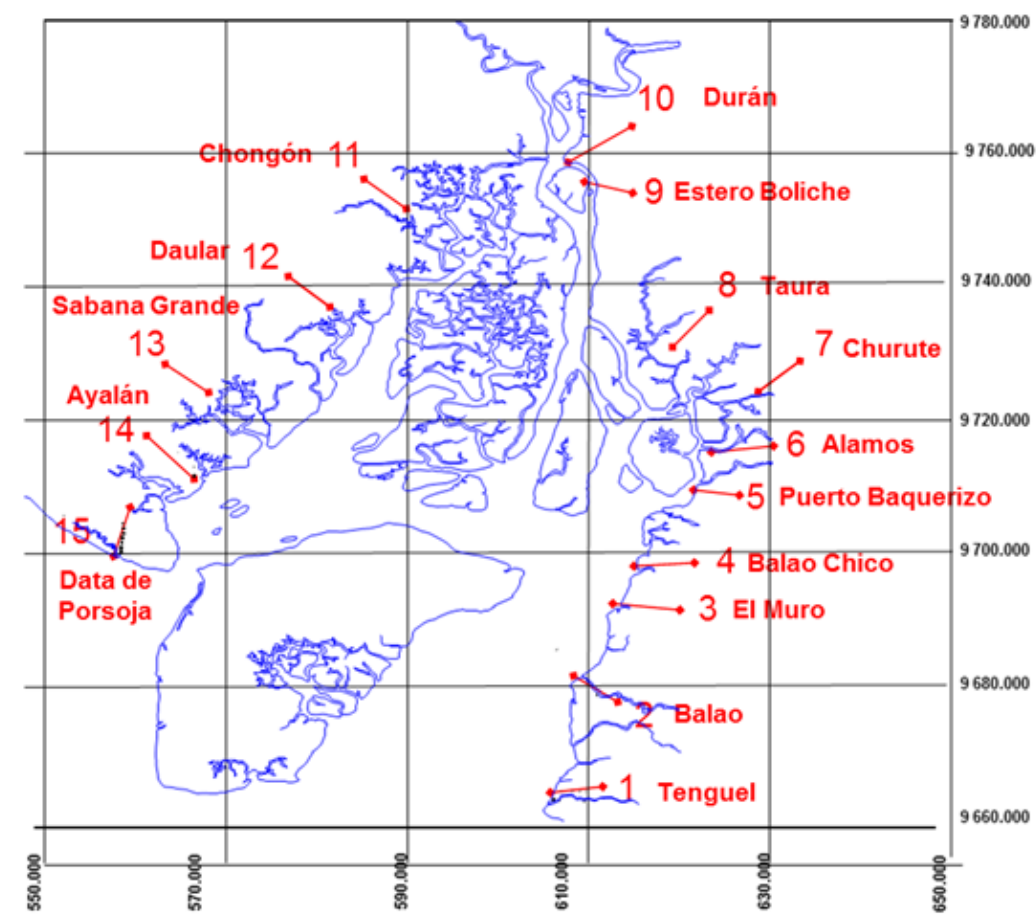

Figure 1. Location of the 15 sampling transects in the Gulf of Guayaquil 


\section{Methods}

\subsection{Physical and Chemical Analyses}

Twelve physicochemical parameters were analyzed including $\mathrm{pH}$, ammonium, phosphorous, organic matter, electrical conductivity, potassium, calcium, magnesium, copper, iron, manganese and zinc. Analyses were performed on the Soils and Spectrometry laboratory of the Faculty of Natural Sciences, University of Guayaquil. The texture was determined using the Bouyoucos aerometric method (Jackson, 1970). The salinity analysis was carried out using the saturation extract method (Allison et al., 1973), while the $\mathrm{pH}$ was assessed with a potentiometer in a 1:2.5 soil-water mixture (Jordan et al., 2004). Ion extraction was conducted with a modified Olsen solution, and the ammonium and phosphorous determination was performed with colorimetry while the metals were found using atomic absorption spectrophotometry. Organic matter was determined the Walkley-Black rapid method (Serrano, 2003). Determining the limits of the CTZ was made by calculating soil salinity indices based on the distances. A $t 0.01$ tests was performed to estimated the differences between the soil salinity averages, from the edge of the mangrove swamp (a) with the other sampling stations (b), (c), (d), (e), and (f) at the $1 \%$ confidence level (Navarro-Pedreño, 2007).

\subsection{Statistical Analysis}

Cluster analysis is a classification technique designed to assign observations to groups in such a way that each group is more or less internally homogenous and thus, different from the others (Majluf, 2002). In the current effort cluster analysis was applied to the 1080 variables that corresponded to the 90 sampling locations. The electrical conductivity, $\mathrm{pH}$, and the concentrations of ammonium, phosphorous, potassium, calcium, magnesium, copper, iron, manganese, zinc and $\mathrm{OM}$ were analyzed. Twelve parameters were quantified in six sampling stations, thus specifying 72 variables for each of 15 profiles covering the GG (Figure 1). The similarity matrix was based on the correlation coefficients for the cluster analysis.

The analysis of variance was conducted for each one of the 12 variables individually, i.e. for the 90 locations, without calculating the effect of distance. The clusters were compared at $\mathrm{pH} 0, \mathrm{pH} 1, \mathrm{pH} 2, \mathrm{pH} 5$, sal0, sal1, sal2, sal5 $\mathrm{pH}$, etc. To include the effect of the distance a mixed-effects model (factorial ANOVA) containing the variables and the distance of the sampling location from the swamp area was afflied. The mathematical expression of the model is given by:

$$
Y i j k=\mu+C i+D j+(C D) i j+\varepsilon i j k
$$

where:

$$
\begin{aligned}
& \text { Yijk = dependent variable in cluster } \mathrm{i} \text {, distance } \mathrm{j} \text {, station } \mathrm{k} \\
& \mu=\text { mean of the dependent variable } \\
& \mathrm{Ci}=\text { effect of the ith cluster } \\
& \mathrm{Dj}=\text { effect of the } \mathrm{jth} \text { distance } \\
& (\mathrm{CD}) \mathrm{ij}=\text { effect of the cluster and distance interaction } \\
& \varepsilon \mathrm{ijk}=\text { error given by the stations }
\end{aligned}
$$

Application of the factorial ANOVA permits to verify if differences in the clusters are related to the interaction between the clusters and the distance from the swamp area.

For the correct interpretation of the data the following consideration were taken into account. If the cluster times the distance interaction is significant the primary effects (cluster, distance) cannot be interpreted since the dependent variables vary with the distance in accordance with the clusters.

Due to such circumstances the interaction averages were generated. From the above discussion it is concluded that if the interaction is not significant the cluster and distance effects can be interpreted individually. The subsequence establishment of the CTZ structure is achieved by the interpretation of the sampling station distribution by cluster.

\section{Results and Discussion}

The salinity value expressed in $\mathrm{mS} \mathrm{cm}-1$ for each sampling station of the 15 transects is listed in Table 1, together with the average, minimum, maximum and the coefficient of variation. The averge conductance value at the mangrove limit is $27.14 \mathrm{mS} \mathrm{cm}-1$. Moving inland the following average values for the conductance were recorded: $29.4 \mathrm{mS} \mathrm{cm}-1,25.2 \mathrm{mS} \mathrm{cm}-1,12.8 \mathrm{mS} \mathrm{cm}-1,5.14 \mathrm{mS} \mathrm{cm}-1$ and $1.39 \mathrm{mS} \mathrm{cm}-1$, for the first, second, third, fourth and fifth kilometer, respectively. 
Table 1 . Soil electrical conductivity (mS cm-1) in the 15 transects measured at 6 distances from the swamp limit $(0,1,2,3,4$ and $5 \mathrm{~km})$, and average, minimum and maximum value and coefficient of variation per sampling distance

\begin{tabular}{crrrrrr}
\hline \multirow{2}{*}{ Transect number } & \multicolumn{6}{c}{ Distance from the swamp limit } \\
\cline { 2 - 7 } & $0 \mathrm{~km}$ & $1 \mathrm{~km}$ & $2 \mathrm{~km}$ & $3 \mathrm{~km}$ & $4 \mathrm{~km}$ & $5 \mathrm{~km}$ \\
\hline 1 & 40.00 & 54.50 & 44.50 & 19.00 & 1.60 & 1.00 \\
2 & 29.00 & 20.50 & 37.00 & 3.80 & 9.50 & 3.20 \\
3 & 30.00 & 35.00 & 16.00 & 2.10 & 1.70 & 1.10 \\
4 & 37.00 & 48.00 & 34.00 & 20.00 & 5.90 & 1.60 \\
5 & 29.00 & 20.00 & 38.50 & 51.00 & 9.30 & 0.67 \\
6 & 11.90 & 23.00 & 25.00 & 14.50 & 1.30 & 0.35 \\
7 & 17.40 & 19.00 & 9.10 & 6.20 & 1.00 & 0.90 \\
8 & 12.30 & 19.00 & 15.00 & 6.60 & 1.25 & 0.52 \\
9 & 17.00 & 19.00 & 38.00 & 15.00 & 12.30 & 6.60 \\
10 & 30.00 & 27.00 & 38.00 & 16.00 & 15.00 & 0.40 \\
11 & 17.50 & 13.00 & 15.00 & 6.50 & 6.40 & 0.40 \\
12 & 29.00 & 20.00 & 12.00 & 9.60 & 1.00 & 0.64 \\
13 & 37.00 & 32.00 & 27.00 & 19.00 & 9.00 & 1.70 \\
14 & 40.00 & 46.00 & 28.00 & 1.60 & 1.30 & 0.70 \\
15 & 30.00 & 45.00 & 1.00 & 0.60 & 0.55 & 0.50 \\
Average & 27.14 & 29.40 & 25.21 & 12.77 & 5.14 & 1.35 \\
Minimum & 11.90 & 13.00 & 1.00 & 0.60 & 0.55 & 0.35 \\
Maximum & 40.00 & 54.50 & 44.50 & 51.00 & 15.00 & 6.60 \\
Coeff. variation & 35.56 & 44.80 & 52.12 & 98.36 & 93.97 & 120.74 \\
\hline
\end{tabular}

A Box-Whisker plot of the soil conductance values is given in Figure 2.

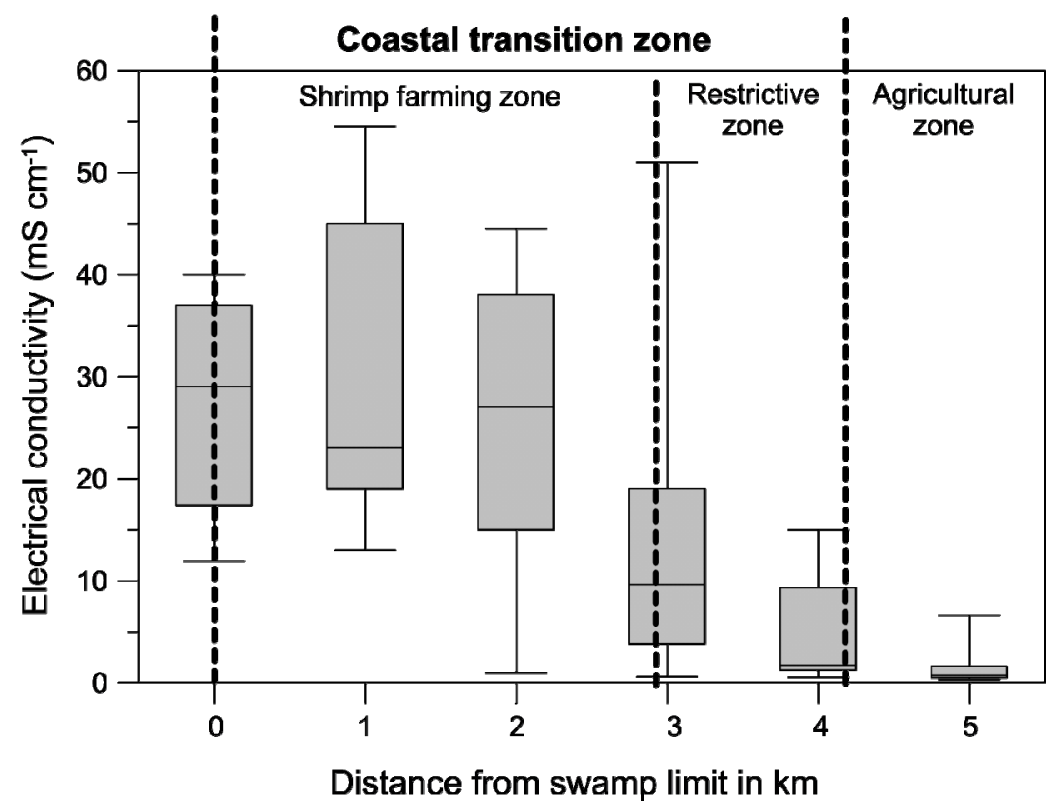

Figure 2. Box-Whisker plot of the soil electrical conductivity $\left(\mathrm{mS} \mathrm{cm}^{-1}\right)$ at the 6 sampling points of the 15 transects 
Figure 2 displays for each of the sampling locations, distance from the swamp border, on the 15 transects the minimum, maximum, median, lower quartile and upper quartile for the electrical conductivity, considered herein as a measure of salinity. From agricultural point of view the electrical conductivity should be equal or less than 4 $\mathrm{mS} \mathrm{cm}{ }^{-1}$, whereas according to Lennon (1977) and Navarro-Pedreño (2007) for shrimp farming the electrical conductivity of the water should be around or larger than $12.8 \mathrm{mS} \mathrm{cm}^{-1}$. Those limits enable to divide the coastal transition zone in a schrimp farming and a restrictive zone. More land inwards the zone suitable for crop farming is depicted. The respective zones are represented in Figure 2 by bold vertical dotted lines. Student's t- test was applied to the average salinity values measured at the 6 distances from the swamp border in order to define differences. This analysis revealed that the salinity level within a distance of $3 \mathrm{~km}$ from the swamp border is distinct different from the salinity level in the transition zone, and that the salinity level in the transition zone is significant different from the farming area, which starts at an average distance of $4.2 \mathrm{~km}$ from the swamp border.

The cluster analysis was applied to the 12 chemical parameters ( $\mathrm{pH}$, ammonium, phosphorous, organic matter, electrical conductivity, potassium, calcium, magnesium, copper, iron, manganese and zinc) measured in the 6 sampling locations of the 15 transects, resulting to a total of 1080 variables. The cluster analysis was conducted to group the 90 stations using the first 13 principal components. By component $1399 \%$ of the total variability of the clusters was explained. The transect distribution on the basis of the cluster analysis is shown by the dendrogram, depicted in Figure 3. A total of three primary clusters can be distinguished. The first clusters groups the sampling transects 3 (El Muro), 13 (Sabana Grande), 15 (Data de Posorja), 11 (Chongón), 12 (Daular) and 14 (Ayalan), while the second cluster represents the transects 5 (Puerto Baquerizo), 10 (Durán), 9 (Estero Boliche), 6 (Álamos), 7 (Churute) and 8 (Taura). The transects 1 (Tenguel), 2 (Balao) and 4 (Balao Chico) represent the third cluster.

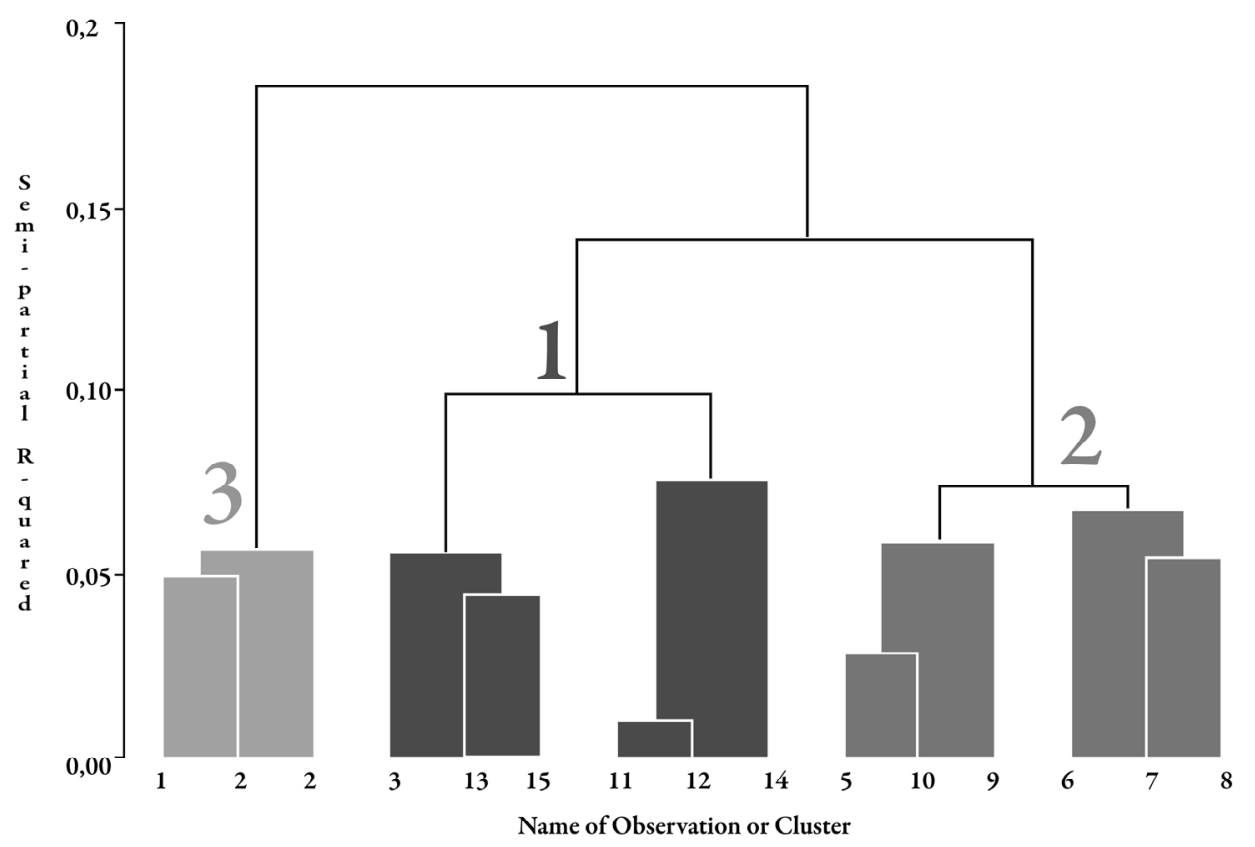

Figure 3. Dendrogram depicting the grouping of the 15 transects in 3 main clusters

An ANOVA analysis was conducted to define if a significant difference exists between the overall characteristics of the clusters. The results from Duncan's multiple variable test confirmed the hypothesis that the clusters are significantly different. The third cluster showed the highest values for the measured physicochemical characteristics, except the $\mathrm{pH}$. The soils in this cluster are the least acid. Some of the physicochemical properties of the topsoil of the transects in clusters 1 (Salinity, $\mathrm{pH}, \mathrm{NH}_{3}, \mathrm{P}, \mathrm{K}, \mathrm{Ca}, \mathrm{Mg}, \mathrm{Fe}, \mathrm{Cu}, \mathrm{Mn}, \mathrm{Zn}$,) are similar with cluster 3, whereas both clusters are significantly different for the other properties (Salinity, pH, $\mathrm{NH}_{3}, \mathrm{P}, \mathrm{K}, \mathrm{Ca}$, $\mathrm{Mg}, \mathrm{Fe}, \mathrm{Cu}, \mathrm{Mn}, \mathrm{Zn}$,). Some physicochemical properties (Salinity, $\mathrm{pH}, \mathrm{NH}_{3}, \mathrm{P}, \mathrm{K}, \mathrm{Ca}, \mathrm{Mg}, \mathrm{Fe}, \mathrm{Cu}, \mathrm{Mn}, \mathrm{Zn}$,) of the topsoil of the transects in cluster 2 are significantly different from cluster 3, whereas not significantly different for the remaining properties. In summary, the clusters 1 and 2 are defined by their similarity or dissimilarity with respect to cluster 3 . 
The cluster and ANOVA analysis reveal that the sampled transects in GG (Figure 4) show that each cluster possesses unique characteristics (Salinity, $\mathrm{pH}, \mathrm{NH}_{3}, \mathrm{P}, \mathrm{K}, \mathrm{Ca}, \mathrm{Mg}, \mathrm{Fe}, \mathrm{Cu}, \mathrm{Mn}, \mathrm{Zn}$,). Cluster 1 situated on the western side of the gulf, cluster 2 is on the north-eastern side and cluster 3 is at the south-eastern side. As stated by Yánez (1986) and Smith (1963) the differences in properties are due to the variable mixing of saltwater and freshwater. Similar results have been presented for the Rio Minho en Rio Sil, forming together the Minho-Sil basin, discharging in the Atlantic Ocean, north-west corner of Spain, where the interaction between the sea and the delta resulted in the formation of a unique marine ecosystem (LOICZ, 2010).

Based on the salinity levels at the border of the 3 salinity zones as depicted in Figure 2 and the results of the cluster analysis, represented in Figure 3, a map with the demarcation of the coastal transition zones of the Gulf of Cuayaquil was drawn (Figure 4). The geographical delimitation of the different zones will help decision-making with respect to the development of new economic fish farming and agricultural activities and the conservation of the delta-land area in the Gulf of Guayaquil. Furthermore, the methodology used can also be used for the quality delimitation of agricultural soils.

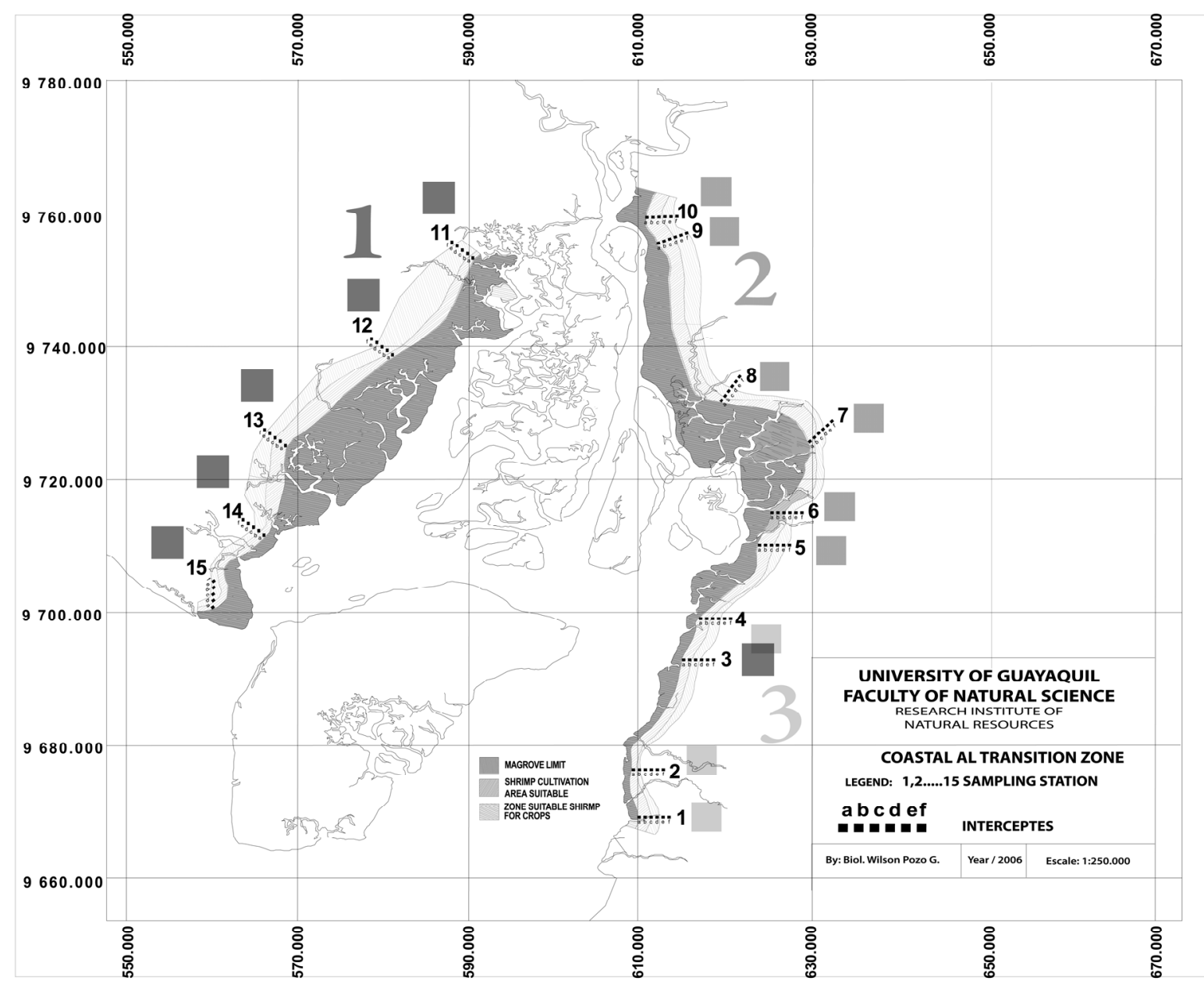

Figure 4. Coastal Transition Zone in the Gulf of Guayaquil

\section{Conclusions}

The current report presents a procedure for the delimitation of the coastal transition zone (CTZ) in the Gulf of Guayaquil, Ecuador, based on the salinity level and the chemical properties of the top layer. The Gulf was chosen as the study area given its importance in marine and agricultural resources, and its unique bio-diversity. The soil salinity was used to characterize the zones in which the salinity level was above $12,8 \mathrm{mS} \mathrm{cm}{ }^{-1}$, zone suitable for schrimp farming and the zone suitable for agricultural farming in which the salinity level is below 4 $\mathrm{mS} \mathrm{cm}{ }^{-1}$. The schrimp farming zone has an average width of $3 \mathrm{~km}$, bordering the swamp area, and the transition 
zone between the shrimp and agricultural farming zones has a width of 1 to $1.2 \mathrm{~km}$. Application of the cluster analysis on the multitude of chemical parameters measured in the 90 locations ( 15 transects, 6 distances per transect) enabled to classify the transects into 3 clusters. Clusters 1 and 2 are defined by either similarity or dissimilarity with respect to cluster 3. Duncan's multiple variable test found significant differences between the groups. The transects in cluster 1 are situated on the western side of the GG, cluster 2 on the eastern side of the GG, and cluster 3 at the entrance of the GG at the eastern side. The study showed the interaction between the marine ecosystem with its own salt water characteristics, and terrestrial ecosystem across the estuary in the Gulf of Guayaquil. Moreover, the Guayas basin draining into the Gulf of Guayaquil contributes to the unique geographic, oceanographic, climate and biodiversity.

The study also revealed the fragility of the studied area due to the industrialization of fish farming and agriculture, and urbanization of which the untreated effluent waters degrade the physical and chemical properties of the swamp area and bordering soils, with negative impact on the biodiversity, and the environment as a whole. To minimize this situation, a series of conservation measures are taken ranging from the adaptation of crop varieties resistant to salinity, as the recovery of saline soils using bioremediation techniques or amendments, and the recovery of mangrove by direct mangrove seeding in shrimp farms to restore the coastal ecosystems and coastal transition zone.

\section{Acknowledgements}

Authors deeply express their gratitude to the Facultad de Ciencias Naturales, of the Universidad de Guayaquil, in particular to Professor Dr. Gilberto Páez Bogarin, Dr. Elkin Bustamante, Dr. Gloria Carrera and Gustavo López for their positive criticism and help during the experimental work and the data interpretation. Special thanks are due to professors Barnett Parker and Jan Feyen for his assistance in the editing of the manuscript.

\section{References}

Allison, L. E., Hayward, H. E., Richards, L. A., Berntein, L., Fireman, M., Person, G. A., ... Reeve, R. C. (1973). Diagnóstico y rehabilitación de suelos salinos y sódicos. Trad. L.A. Richardas $6 a$ ed. México, Limusa, $172 p$.

Barton, E. D., \& Arístegui, J. (2004). The Canary Islands coastal transition zone- upwelling, eddies and filaments. Progress in Oceanography, 62(2-4), 67-69. http://dx.doi.org/10.1016/j.pocean.2004.08.003

Brady, N. C. (1974). The nature and properties of soils (8th ed.). New York: Macmillan Publishing Co. 639p.

Bravo, E. (2003). La soberanía alimentaria en el Ecuador: El caso de la industria camaronera. In: Globalización y Agricultura. Jornadas para la Soberanía Alimentaria. Barcelona, España, 11p.

Brink, K. H., \& Cowles, T. J. (1991). The coastal transition zone program. Journal of Geophysical Research, 14, 14637-14647. http://dx.doi.org/10.1029/91JC01206

Comision Asesora Ambiental de la Presidencia de la Republica (CAAM). (1996). Desarrollo y problemática ambiental del Golfo de Guayaquil, 354p.

Comisión Permanente Del Pacífico Sur (CPPS). (2006). Secretaría Ejecutiva del Plan de Acción para la Protección del Medio Marino y Áreas Costeras del Pacífico Sudeste. River Basin of Minho-Sil.

Jackson, M. L. (1970). Análisis químico de suelos y plantas. Ed. Omega, Barcelona, Spain.

Jordán, M. M., Mateu, J., Juan, P., Navarro-Pedreño, J., \& García Sánchez, E. (2004). Spatial dynamics of soil salinity under arid and semiarid conditions: geological and environmental implications. Environmental Geology, 45, 448-456. http://dx.doi.org/10.1007/s00254-003-0894-y

Land-Ocean Interactions in the Coastal Zone (LOICZ). (2010). Core Project of the International Geosphere-Biosphere Programme: A Study of Global Change (IGBP) and the International Human Dimensions Programme on Global Environmental Change (IHDP). Compiled and edited by: Gordeev, V. V., Andreeva, E. N., Lisitzin, A. P., Kremer, H. H., Salomons, W., \& Marshall Crosslan, J. Y. LOICZ Reports and Studies No. 29.

Lennon, L. (1977). Química de suelos con enfoque agrícola Ed. Chapingo México, 278p.

Majluf, P. (2002). Proyecto Estrategia regional de biodiversidad para los países del trópico Andino. Convenio de cooperación técnica no reembolsable ATN/JF-5887/RG CAN-BID. Lima, Perú.

Martino, E. J., \& Able, K. W. (2003). Fish assemblages across the marine to low salinity transition zone of a temperate estuary. Estuarine Coastal and Shelf Science, 56, 969-987. http://dx.doi.org/10.1016/S0272-7714(02)00305-0 
Montaño, M. (2010). Ecosistema Guayas (Ecuador): Recursos, medio ambiente y sostenibilidad en la perspectiva de conocimiento tropical. Tesis doctoral, Departamento de Agroquímica y Medio Ambiente. Universidad Miguel Hernandez de Elche, Alicante, Spain, 266p.

Montaño, M., \& Sanfeliu, T. (2008). Ecosistema Guayas (Ecuador). Medio ambiente y sostenibilidad. Revista Tecnológica ESPOL, 21, 1-6.

Navarro-Pedreño, J., Jordán, M. M., Melendez-Pastor, I., Gómez-Lucas, I., Juan, P., \& Mateu, J. (2007). Estimation of soil salinity in semi-arid land using a geostatistical model. Land Management \& Development, 18, 339-353.

Redmanglar Internacional. (2002). Conservacion del Manglar. Retrieved from http://www.redmanglar.org/

Richards, L. A. (1954). Diagnosis and improvement of saline and alkali soils. Washington, D.C: United States Salinity Laboratory, United States Department of Agriculture Handbook, 60, 160p.

Serrano, G. (2003). Introducción al análisis de datos experimentales: Tratamiento de datos de bioensayos. Universidad Jaume I., Castellón, Spain, 103-143.

Smith, G. D. (1963). Objectives and basic assumptions of the new soil classification. System Sciences, 96, 6-16.

Yánez, A. (1989). Lagunas costeras estuarinas: Cronología criterios y conceptos para una clasificación ecológica de un sistema costero. UNAM, Editorial Universitaria, México.

Yáñez, A. (1986). Ecología de la zona costera: análisis de siete tópicos. AGT Ed., México, 189 p. 